
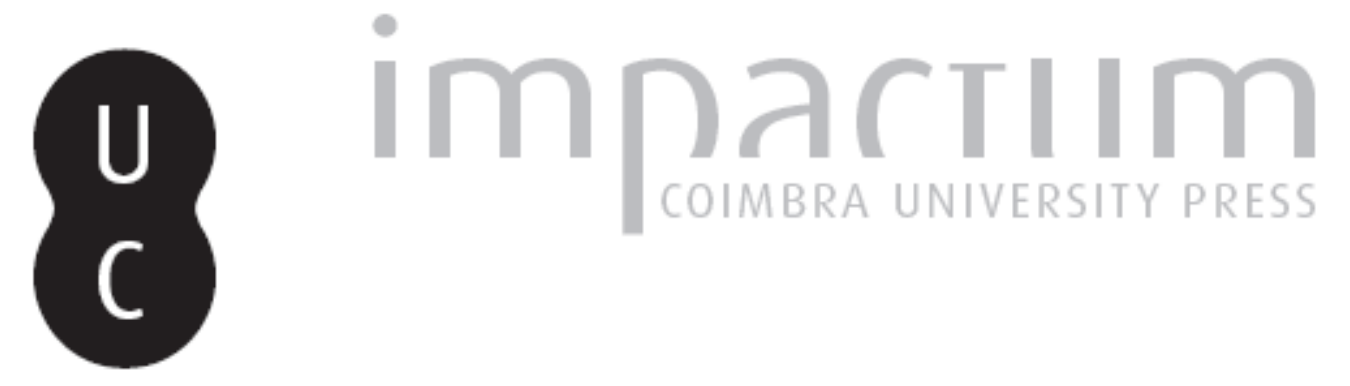

\title{
Imag(in)ing: media and literature in Don Delillo's Falling man
}

Autor(es): $\quad$ Simões, Marta de Sousa; Almeida, Jorge Alexandre

Publicado por: Imprensa da Universidade de Coimbra

URL persistente:

URI:http://hdl.handle.net/10316.2/35513

DOI:

DOI:http://dx.doi.org/10.14195/0870-4112_11_15

Accessed : $\quad$ 26-Apr-2023 13:49:50

A navegação consulta e descarregamento dos títulos inseridos nas Bibliotecas Digitais UC Digitalis, UC Pombalina e UC Impactum, pressupõem a aceitação plena e sem reservas dos Termos e Condições de Uso destas Bibliotecas Digitais, disponíveis em https://digitalis.uc.pt/pt-pt/termos.

Conforme exposto nos referidos Termos e Condições de Uso, o descarregamento de títulos de acesso restrito requer uma licença válida de autorização devendo o utilizador aceder ao(s) documento(s) a partir de um endereço de IP da instituição detentora da supramencionada licença.

Ao utilizador é apenas permitido o descarregamento para uso pessoal, pelo que o emprego do(s) título(s) descarregado(s) para outro fim, designadamente comercial, carece de autorização do respetivo autor ou editor da obra.

Na medida em que todas as obras da UC Digitalis se encontram protegidas pelo Código do Direito de Autor e Direitos Conexos e demais legislação aplicável, toda a cópia, parcial ou total, deste documento, nos casos em que é legalmente admitida, deverá conter ou fazer-se acompanhar por este aviso.

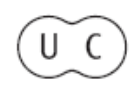




\section{ESTÉTICA E POLÍTICA}

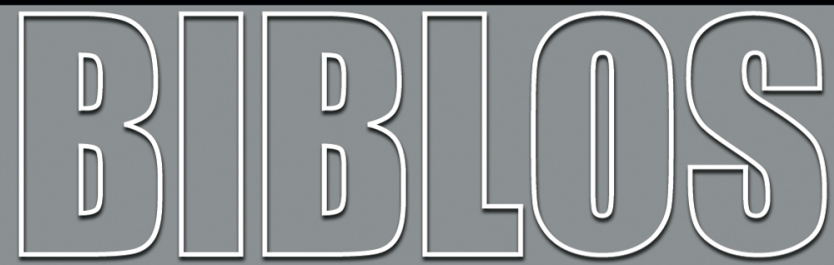

REVISTA DA FACULDADE DE LETRAS UNIVERSIDADE DE COIMBRA 
Biblos, n. s. XI (2013) 357-372

DOI: http://dx.doi.org/10.14195/0870-4112_11_15

Marta de Sousa Simões

Escola Superior de Tecnologia e Gestão de Oliveira do Hospital

Instituto Politécnico de Coimbra

Jorge Alexandre Almeida

Instituto Superior de Engenharia de Coimbra

Instituto Politécnico de Coimbra

\section{IMAG(IN)ING: MEDIA AND LITERATURE \\ IN DON DELILLO'S FALLING MAN}

\section{Resumo}

A sociedade moderna é profundamente icónica e os conceitos culturais tornam-se mais dinâmicos devido à profusão de imagens que moldam as nossas vidas diariamente, através dos mass media.

Milhões de imagens que são transmitidas tornam-se a matéria-prima da Arte e Literatura, tal como o "Falling man" - uma foto emblemática de um homem a cair de uma das torres, no 11 de setembro - é um exemplo perfeito.

Os mass media têm um papel importante no moldar de uma consciência pública. A Arte pode ser analisada como uma história dentro da História, proporcionando uma nova leitura e foco nesta obra de Don DeLillo - Falling Man (2007). Há uma harmonia entre discurso narrativo, mass media, memória e Arte na América contemporânea.

O objetivo deste artigo é lidar com imagens e com a Arte (Literatura) enquanto conhecimento da perceção pública do terror/trauma. As imagens tornam-se o começo de um processo de catarse que se desenvolve na escrita do autor e acaba na leitura do público.

Palavras-chave: Falling Man, Mass Media, Arte e Literatura, Terror/ Trauma.

\footnotetext{
Abstract

Modern society is deeply iconic and cultural concepts become more dynamic due to the perfusion of images that shape our lives daily through mass media.
} 
Millions of images that are broadcast become the raw material of Art and Literature, as the "Falling Man" - an emblematic photo of a man falling down from of the towers on the 11th September - is a perfect example.

The mass media have an important role shaping the public conscience. Art can be analysed as a story inside the story, giving a new reading and focus on Don DeLillo's novel - Falling Man (2007). There's a harmony between narrative discourse, mass media, memory and Art in contemporary America.

The aim of this paper is to deal with images and Art (Literature) as an insight of public perception of terror/trauma. Images become the beginning of a catharsis process that develops in the writing of the author and ends in the reading of the public.

Keywords: Falling Man, Media, Art and Literature, Terror/Trauma 


\section{Image(ry)}

Im.ag.e.ry (= words used to describe things)

"The images we see and recall interact with our system of metaphors. The results can be powerful. A common visual metaphor is Buildings Are Heads, where windows and doors are openings in the head like eyes, nose, and mouth. For many people, this metaphor interacted with the image of the plane going into South Tower of the World Trade Center, producing via visual metaphor the unconscious, but powerful image of a bullet going through someone's head, the flame pouring from the other side blood spurting out.

Tall buildings can, via visual metaphor, be people standing erect. For many the falling of the towers activated this metaphor. Each tower falling was a body falling. We are not consciously aware of the metaphorical images, but they are part of the power and the horror we experience when we see them. (...)

If we metaphorize the building as a person and see the building fall to the ground in pieces, then we sense-again unconsciously but powerfully - that we are falling to the ground in pieces. Our systems of metaphorical thought, interacting with mirror neuron systems, turn external literal horrors into felt metaphorical horrors."

"The Power of the Images" is the expression used by George Lakoff to refer to a phenomenon that we are all vulnerable and exposed to - the metamorphosis of the images, especially those that are empowered by the media - into metaphors that are meaningful and change our perception of the world. This is an ever-lasting process, an autonomous engine fuelled by History itself and by the instinctive human need to "be aware". Nowadays, in our profoundly technological era, that need is "urgent" and politicised through the notion that citizens MUST "be aware", updated and cultivated, and that broadly means that, through Information and Communication Thechnology ICT, the media have gained a powerful new role: being available worldwide, the media are "windows on the world", an unstoppable vehicle of information transmission: daily, hourly and instantly.

George Lakoff referred in his article to a specific event: 9/11. Connecting the title "September 11, 2001" with the subtitle 1. The Power 
of the images, is a logical equation. After all, 9/11 was the most photographed and videotaped day in the history of the world. It is not the purpose of this article to focus on the political, economic, religious, or any other well-known reasons why $9 / 11$ is an endless issue to the mass media. It is and it will continue being, "a muse" for journalists, reporters, photographers, writers, poets and all artists in general, that every year, in that same date (or not), exercise a grieving memory and pay tribute to the victims and to America itself, in a slow-motion flashback, a backwards review of 9/11 data. In a psychoanalysis-like effort, we are invited to (re)think the identity of the "Empire" - the United States of America - through memory, in a catharsis process of a voyeur nation that copes better with loss than with guilt.

The images that portrayed this traumatic event for Americans are countless, and some of them (especially the ones of the "jumpers") were quickly considered "taboo", censured and banished from their sources as the nation emphasized the lack of respect for the families of those so dying. The images of 9/11 appeared as photos, videos, documentaries, websites; along with the articles and books written, the desperate and painful messages broadcast to the world by politicians and anonymous citizens (either relatives of the victims or not) all demanding new concepts to best express the terrorist attack that dared showing the world that the "Gold Mountain" was not immortal, untouchable and secure. Amy Kaplan's "In the Name of Security" presents a historical and cultural etymology of the concept "Security" showing the melting of the domestic into the foreign and the building of the keyword "homeland" to stand for the idea of national security, domestic security and civil defence. In fact, security, as Susana Araújo refers in the article "Security Unlocked and Fictions of Terror", was seen:

“(...) not only as policy, but as culture, as a central theme of official discourse (...). Narrative and fiction have always been fundamental to the construction of national self-images, as justifying means for political and military expansion. In this sense it may be opportune to draw on contemporary fiction as a way of seeing through the fictionalization of our national portraits. (...)"

Security becomes a "way of life" built in metaphors of fear, associated to panic, surveillance, invasion of privacy, control, suspicion, 
trauma and amnesia, which inspire popular American culture in the presentation of vigorous remasculinized heroes that, incessantly, fight against an enemy whose undefined identity connects to fundamentalism and to the stereotypes of the Arab terrorist.

\section{2. $\operatorname{Imag}(e)$ ination}

Im.ag.in.a.tion (=ability to form mental pictures or ideas).

9/11 is a symbiosis of reality and fiction/fantasy, whose frontiers are blurred, mainly because of the awareness of a "precariousness of life", dramatically emphasized by media coverage. Slavoj Zizek, in "Welcome to the Desert of the Real", states that the terrorist attacks are, indeed, a fulfilment of an imagined or fantasized retaliation. The United States are compelled into a forced and sudden identity review that had its origin in the event itself, along with the expression of a new discourse dialectics: fictional and analytical discourse. Post 9/11 fictional discourse is deeply dynamic, rooted in a sense of acceptance/rejection of the analytical one, being both immersed in a context of political repositioning, of geographical remapping and identity reconstruction.

Mass media were crucial in the propaganda of the analytical discourse as many critics and sociologists proved. Altheide, for example, showed that news management contributed to a discourse of fear and symbolic negation of the "other", criminal or terrorist, and intended to worship criminal conduct as necessary and heroic. Fredric Jameson in "The Dialectics of Disaster" analyses the way in which the media have represented 9/11, through unrealistic visuals causing an amalgamation of media sentiment and emotion, that is, a metaphorical rhetoric, symbolic and connotative, based on the ever-present threat came from the Barbarian outside.

The fictional discourse is immediate and broad, deeply embedded in the need to reassure that memory would pervade over amnesia and that not only "Ground Zero" would pay a tribute to the victims, to their families and to America itself; but also Literature. While some authors intend to pay homage to the dead and to a "mourning nation"; others are deeper, more critical and identity mirroring. The list of novels, poems, short stories, among others, goes on and on, meaning that liter- 
ary profusion was deeply related to a sense of commitment through authorship. Writers performed their roles as keepers of historical record through writing, in a complex individual $v s$ collective memory exercise between three timelines: past, present and future. They all have in common the western society's supremacy model of permanent utopia and perennial empire. The writing of stories becomes a platform for dialogue, conflict, verbalization and personal repositioning in relation to History. Authorship and writing become crucial in the reconstruction of the American Identity through the private lives of main characters that are also haunted by fears. Fiction allows a mimetic process in the building of characters in relation to American citizens.

We believe that there was/is a powerful dynamics between facts and fiction in what the $9 / 11$ is concerned, due to the media "spectacle" around it - one of the most traumatic days of the American history. From the endless list of “9/11 based" Literature, DeLillo's Falling Man stands out for its obvious connection to the most emblematic photo taken that day, by $A P$ 's photographer Richard Drew. Later entitled "The Falling Man", the photo first appeared on $12^{\text {th }}$ September 2001 in The New York Times, on page 7, as well as on hundreds of newspapers worldwide. It appeared once in each source and never again, as Tom Junod explains later on, in his article "The Falling Man" published in Esquire, September 8, 2009:

"In most American newspapers, the photograph that Richard Drew took of the Falling Man ran once and never again. Papers all over the country, from the Fort Worth Star - Telegram to the Memphis Commercial Appeal to The Denver Post, were forced to defend themselves against charges that they exploited a man's death, stripped him of his dignity, invaded his privacy, turned tragedy into leering pornography. Most letters of complaint stated the obvious: that someone seeing the picture had to know who it was. Still, even as Drew's photograph became at once iconic and impermissible, its subject remained unnamed."

The "Falling Man" is a striking and breathtaking image mainly because of its verticality, bearing straight symmetric lines as background for a falling human body, knee-bent, defying gravity. These characteristics separate this one photo from the rest of "the jumpers", whose poise was suicidal-like, being therefore even more subject to 
censorship. The sequence of photos of the "Falling Man" showed several details concerning his face, complexion and outfit, which made an editor at the Toronto Globe and Mail assign a reporter - Peter Cheney - to solve the mystery of the "Falling Man's" identity. In the end he had a void: no answers, no identity, although several options were brought to investigation, leaving the alleged families in anguish and hatred towards the reporter who was seeking a name (and thus, staining it) for the "deaths unworthy of witness", as patriotic Americans called them. Tom Junod concluded that:

" (...) the man buried inside its frame - the Falling Man - became the Unknown Soldier in a war whose end we have not yet seen. Richard Drew's photograph is all we know of him, and yet all we know of him becomes a measure of what we know of ourselves. The picture is his cenotaph, and like the monuments dedicated to the memory of unknown soldiers everywhere, it asks that we look at it, and make one simple acknowledgement. That we have known who the Falling Man is all along."

What the excerpt enhances are the dichotomies - private and public - History and story - present in the framing of citizenship and sense of belonging, crucial to overcoming the identity crisis that America was endeavouring. Images such as the "Falling Man" demanded narratives, stories of private lives that can anchor the surreal iconic to reality through semiotics, as a way of exorcizing fear and the "ghosts" of 9/11. Writing and memory have always played an important role in the shaping of national identities.

Don DeLillo's Falling Man is a perfect example of post 9/11 writing using emblematic images (the "Falling Man's" image/photo) and the intensive media coverage as a motto for the narrative's purpose to exploit the idea of fall and decadence of the American empire and society.

She did not read further but knew at once which photograph the account referred to. It hit her hard when she first saw it, the day after, in the newspaper. The man headlong, the towers behind him. The mass of the towers filled the frame of the picture behind him. The mass of the towers filled the frame of the picture. The man falling, the towers contiguous, she thought, behind him. The enormous soaring lines, the vertical column stripes. The man with blood on his shirt, she thought, or burn marks, and 
the effect of the columns behind him, the composition, she thought, darker stripes for the nearer tower, the north, lighter for the other, and the mass, the immensity of it, and the man set almost precisely between the rows of darker and lighter stripes. Headlong, free fall, she thought, and this picture burned a hole in her mind and heart, dear God, he was a falling angel and his beauty was horrific."

Divided in three parts, as for three identities: Bill Lawton; Ernst Hechinger and David Janiak, Falling Man starts with the description of the scenario of $9 / 11$ chaos, fall and terror, experienced by faces in collapse. There are visual sensations of the North Tower fall that give readers the idea of a fast sequence of terrifying blurred images, due to smoke and ash, frantically mixing reality, fiction and the writer's imagination. The blending of stories with History is expressed through the private lives of a family in which the terrorist attacks have imprinted severe damage. To emphasize the identity loss/questioning, the author refers to characters through the use of personal pronouns, "he"/"she", that are undefined, faceless and bodiless. In fact, the novel exploits the visual in a fragmented way: besides presenting different perspectives, angles and brightness; it also dives deep into physical and psychological mutilation. This last one is portrayed in the collapse of the characters' private lives, especially through broken marriages and memory losses.

The author refers to "bodies incomplete" (p. 7) building a clear frontier between the before and after $9 / 11$. The only thing that appears complete, unquestionable and beautiful is, in fact, Art itself: poetry "(...) it was clear that the cover was beautifully designed (...) Revolt of Islam. The card was from the Keats-Shelley House in Piazza di Spagna (...)" (p.8); but also other arts present in the Metropolitan Museum (p.11), where the American identity remained untouched.

Trauma invades the novel every time the narrative focus goes into war scenarios, that aren't anchored in time or space references: they appear as flashes of memory, invoking the reports given by war veterans after returning from conflict areas/war, while dealing with posttraumatic stress. There's a whole nation suffering from this disease and DeLillo's novel illustrates it through the description of a wandering mob: groups of people that wander in the multicultural streets; in addition to other help groups in therapy (for many different reasons). 
Writing and reading about planes is seen as a crucial "therapy", not only to write about History and its traumatic events, but also to exercise memory, threatened by Alzheimer or senility. Family, one of the most important American institutions, appears deeply injured and deconstructed by 9/11: instead of playing, children spend their time in surveillance, scanning the skies for planes, and couples are either in crisis or apart. The other communicational activity, speaking, is also scrutinized through the Falling Man's narrative: the main character, Keith, is unable to verbalize $9 / 11$, and his son spoke in monosyllables, or in an unclear way, as the spelling of "Bill Laden" is an example, as Part I expresses: Bill Lawton - childish language for the true terrorist's name. DeLillo's focus goes into the role of mass media and to media discourse proliferation in opposition to the communicative inability of characters to express thoughts and feelings. Their discourse is blocked by numerous threats: the reference to "unattended packages $(\ldots)$ or the subway at rush hour and (...) sealed boxes" (p. 127).

In the novel, the "Falling Man" - David Janiak - is a performance artist: "Falling Man was known to appear among crowds or at sites where crowds might quickly form. (...) He stood balanced on the rail of the platform. (...) He loomed over the sidewalk, legs spread slightly, arms out of his body and bent at the elbows, asymmetrically, man in fear, looking out of some deep pool of concentration into lost space, dead space". (p. 164)

The dialogue between the original photo of the "Falling Man" and DeLillo's novel is dynamic, clear and highly symbolic:

"There is some dispute over the issue of the position he assumed during the fall, the position he maintained in his suspended state. Was this position intended to reflect the body posture of a particular man who was photographed falling from the north tower of the World Trade Center, headfirst, arms at his sides, one leg bent, a man set forever in free fall against the looming background of the column panels in the tower? (...) (p. 221)

\section{Imag(in)ing}

“(...) Theirs (Americans) is a crisis of an achieved utopia, confronted with the problem of its duration and permanence. The Americans are not wrong 
in their conviction that they are at the centre of the world, the supreme power, the absolute model for everyone. And this conviction is (...) a utopia made reality, of a society which, with a directness we might judge unbearable, is built on the idea that it is the realization of everything the others dreamt of - justice, plenty, rule of law, wealth, freedom: it knows this, it believes in it, and in the end, the others have come to believe in it too."

Don DeLillo's Falling Man novel shows a trajectory of terror within a non- linear path from the starting point, where the reader's journey starts, with an injured, dazed, ash covered Keith Neudecker wandering the streets of New York, until the end of the book, where DeLillo places again a bleeding, glass shards covered and confuse Keith wandering in the city. These starting and ending points - a geography of physical and imagery boundaries - of the novel have in common the falling Twin Towers after the planes crashed. The focus on the north tower collapse suggests an analogy between the tower and the American society: the fall of the Empire. From this trajectory, one may consider different approaches in the Media and Art domains because the perception changes as the novel's main characters dive into the atmosphere of confusion and chaos.

DeLillo clearly forces the reader to take part in the artistic and aesthetic travelling through the American society adrift with the loss of a previous ubiquitous sense of security, as New Yorkers spin into a redefined "injured" world where very little is granted and a lot is being questioned. These disturbances and disorders shaped or warped the perception of cultural values and turned Falling Man into a novel of (re) imagery, displaying the dialectics: terror as art and art as terror; trauma as fear and fear as trauma.

The author successfully dissects and indoctrinates suffering and horror, forcing readers to face a new America post 9/11, and conforms that event to a work of literature that praises the role of arts in the nation's redefining of newly empowered concepts such as terror, threat, panic, fear, surveillance, powerlessness, danger, terrorism, exposure and trauma. The reader is induced to the idea of unstable duality and permanent confusion between reality (or the perception of reality) and fiction - like an eyes-wide-open, sometimes naive, view over fear and death's live coverage. The image of a man falling down from a tower 
is a metaphor for the ending of the security myth based on global and worldwide leadership.

The Towers collapse opened a new timeline: the immergence of a "risk society", in the words of Anthony Giddens. A society haunted by the idea of permanent threat (terrorism, anthrax, among others) and by the permanent need for protection - a never before experienced schizophrenia state of mind.

Lawyer Keith Neudecker is a leitmotiv for any American citizen wandering in the streets of New York. In fact, thirteen years after 9/11, the falling man's image is not anachronic nor out of real coordinate space and it can perfectly be a metaphor for the geography of the self in the sense that the falling man is a hyponym for the American society on the quest to recover from a traumatic experience. The falling man's image and its worldwide impact through media coverage still represents the endeavour of overcoming that event. It's a visual manifest or "performance art" in the trauma mapping. 9/11 was witnessed by millions on $\mathrm{TV}$, differently from other international attacks, since terror was no longer a faraway picture like Gaza or Iraq, but this time inside borders, in the "homeland", creating for Americans a new geography of terror, whose epicentre is New York City, the heart of America. That geographic "risk displacement" changes positions between the "safe national" and the "unsafe international", abolishing the protection of boundaries and so demanding an insight into American security or the lack of it and, consequently, the creation of a highly protective legal system.

The mass media and Arts play an important role shaping the public conscience and making society cope with all kinds of political, legal, or ideological changes. Whereas the political discourse is exacerbated, anxious and angry; Arts and Literature give a cunning vision of terror, most of it based in photographs or videos giving a hyper-reality of 9/11 and post 9/11 America. They offered guidelines for the new behaviour to be adopted by American society. Terror emerged in the security zone never attacked before, reshaping America into a vulnerable country and thus forcing its citizens to adopt new attitudes, thoughts and defences.

The changing of space perception and the altering geography of the self was boosted by the "culturization" of fear, rooted in the American media as never before. The American empire brought new values to society, after the $9 / 11$, changing priorities from economy to security. DeLillo's thinking suggests that society is not likely to be naturally 
secure but the events pushed the self-sacrificing defence status to the highest level. The motivation is clear from citizens' groups to federal government policies under a strain of revenge. The new frontier of fear can be read as an assertion that an understanding of the terror nature could identify the means by which America was attacked. But this time, there's not a country to blame but some fuzzy terrorist groups, also suggesting a new kind of America and Western enemies. It might help further reflection trying to sort Art and media behaviour: the behaviour of the media projecting new values of culture, showed a great impact in society as can be easily asserted by the fraying worldwide reproduction of the "Falling Man's" image in newspapers and television and the Internet. The huge impact of this image linked forever media to fear and trauma. The society's cultural and physical frontiers had a new foundation of values and a question arose: what is now essential for America? And the words "protection", "security" and "defence" surpassed the old spectrum of economic power and welfare values for a "fitting in" society of control. It was time to establish new ideas, concepts and values and that new perception of life was given and underlined by mass media and Art, especially Literature. The new source of ideas brings a new approach for citizen's thinking and redefining priorities. It was time to seriously enhance America's self-defence in the evidence of 9/11 terror. But how did America exchange values, trough media and Art and still be America? What indeed changed in the 9/11 aftermath? The citizens' perception of risks and the idea of eminent empire fall target issues in the analytic discourse widely emphasized by countless headlines bombarded by mass media.

DeLillo writes about death and trauma using a photograph showing a falling man as the epicentre of violence and a starting point. Literature "framed" that image capturing all the reader's senses. There's also a clear convergence of two powerful forces describing horror: DeLillo's writing in one hand and media broadcast on the other. The flood of images and the strong impact of the 9/11 coverage has defined a new frontier for media broadcast and, of course, Art representation of this crucial event in the American society and history. The security's new frontiers in the context of the 9/11 changed the cultural values: the post9/11 era disintegrates brutally the illusion of Empire's unattainability, the one which succumbed through the "display" of a terrorist attack causing death, horror and confusion. The illusion of a geography of 
comfort and security is lost and landmarks are brutally invaded towards America's heart - economically (WTC) and ideologically (a symbol of the American power). The mass media represented the possibility to testify that event and to be part of History. Again, several questions must be asked: in the absence of pictures or TV broadcast, would trauma, anxiety and stress's intensity be the same? Would that historical event be the same? How deeply did the illusory infinite "dive" of the "falling man" into the void shock America and the world? How did Art/Literature and media representation of America's disintegration shape society's view of terror and, consequently, trauma? How does trauma behave? Does it arise from reality or from fantasy? Bottom line: is $9 / 11$ representation of reality just a materialization of fantasy and imagination or is it the opposite? A fact: we live in a deeply iconic society - one that is unliveable without image consumption through media fast-food. Could the absence of images lead to absence of trauma? Could trauma only exist if a media proof or representation of it was produced? "Memorializing" 9/11 is a catharsis process or is it a trauma exploitation? It is deeply a matter of meta-representation. DeLillo's writing asks questions like these in an implicit story inside a story and leaves endless questions to readers. The writer's greatest achievement is not in the answers, but in all the questions that readers are forced to answer themselves, concerning the present, but also the past. Exercising memory through writing becomes a therapy, one that relies on the verbalization of trauma and terror to the overcoming of fear, allowing the identity reconstruction. 9/11 has infinite multimedia data study in the next decades and the thirteen years gap from which we critically analyse it nowadays gives us a narrative frame of other subsequent events: the empire stroke back, $\mathrm{Al}$ Qaeda leader was killed in Pakistan and the Empire progressively reestablished its security, or illusion of it. Of course, Bin Laden's death was crucial for America, in a way that it rehabilitated the image of the American hero and it re-empowered America by the strengthening of three timelines: the stereotypes of the past, the reconstruction of the present and the projection of hope for the future. America reconciled with its own past. The media, again, reproducing Bin Laden death's helped society to endorse a therapy against "post $9 / 11$ fear phobia", exorcising it through continuous pleasuring viewing of Bin Laden's death and, now, Al Qaeda's pain and defeat by the hands of the American soldiers - America's heroes. The event is highly symbolic and meta-narration 
plays an important role in the geography of trauma and fear, the displacement of it, from America to elsewhere. The presence or absence of images or Art representation influences the strength or authenticity of this 9/11-related event. Literature as art travels through time and space in a continuous process of memory imprinting and identity reconstruction. Of course, any image could be analysed through different perspectives. This metalevel of imaging or reimaging the events moves on to literature where DeLillos's writing exercises imagination, making the reader question reality through the representation of it. The testimony of the fall and the writing of it is not only a symbol or representation of the empire's fall - present; but a starting point of open possibilities - future.

The new geographic frontiers of fear and trauma for America in the XXI Century must have a critical analysis between reality and its representation. Images became multi-dimensional because they gained more expression when (re)imaged later through Arts and Literature. DeLillo's Falling Man displays a society haunted by a traumatic experience and deals with a new geography of the self, one that clearly enlargers and strengthens frontiers towards the "other".

The fictionalization of security by DeLillo gathers the public and private sphere in the understanding of 9/11 as a central event in America's history. DeLillo's story inside the story, presenting a dysfunctional family, touches one of the deepest 9/11 open wounds: the private lives of all the victims, their families and their suffering after the WTC fall. The trauma and the proliferation of fear, throughout DeLillo's fiction, illustrates a new dynamics in the geography of security, since the novel deconstructs our old view of impenetrable frontiers creating a new sense of fast moving borders as the world is a fast changing system. The risk perception acts within a new paradigm: nothing is safe and everything is assumed changing like a non-ending alignment between what is beyond our eyes and what really happened. This new perception of security was the genesis for a security culture and the beginning of a new era of securitization. DeLillo's work opened several ways for a better understanding of 9/11 event with a narrative (fiction) that shaped reality, melting images with imagination.

"The dramatic climb of the Dow and the speed of the Internet summoned us all to live permanently in the future, in the utopian-glow of cyber-capi- 
tal, because there's no memory there and this is where markets are uncontrolled and investment potential has no limit.

All this changed on September 11. Today, again, the world narrative belongs to terrorists. But the primary target of the man who attacked the Pentagon and the World Trade Center was not the global economy. (...)It is the power of American culture to penetrate every wall, home, life and mind. Terror's response is a narrative that has developing over years, only now becoming inescapable. (...)

The Internet is a counter-narrative, shaped in part by rumour, fantasy, and mystical reverberation.

The events of September 11 were covered unstintingly. There was no confusion of roles on TV. The raw event was one thing, the coverage another. The event dominated the medium. It was bright and totalizing, and some of us said it was unreal. (...)"

\section{References}

Amy Kaplan, "In the Name of Security", Review of International American Studies, Special Issue: on Terror and Security, N. 3.3-4.1 (2008), p. 15 -p. 24.

D. L. Altheide, “Mass Media, Crime and Terrorism”, Journal of International Criminal Justice, 4 (5), (2006), p. 82-97.

Don DeLillo, "In The Ruins of The Future: Reflections on Terror and Loss in the Shadow of September", "Harper's Magazine, December 2001, p. 33-40.

Don DeLillo, Falling Man, New York, Scribner, 2007.

Fredric JAmeson, “The Dialectics of Disaster", The South Atlantic Quarterly, vol. 101 (2), (2002), p.297-304.

George Lakoff, "September 11, 2001". Frameworks Institute, (available at frameworksinstitute.org/assets/files/.../9-11-01.pdf, consulted in 2014.01.25)

Joseph M. Conte, "Falling Man and the Age of Terror" MFS Modern Fiction Studies, Volume 57, Number 3, Fall 2011, John Hopkins University, pages 557-583, 2011.

Judith Butler, Precarious Life: The Powers of Mourning and Violence, London, Balfour, 2004. 
Susana Araúso, "Security Unlocked and Fictions of Terror", Review of International American Studies, Special Issue: on Terror and Security, N. ${ }^{\circ} 3.3$ -4.1 (2008), p.5-p.14.

Susana Araúso, "Images of Terror, Narratives of Captivity: The Visual Spectacle of 9/11 and its Transatlantic Projections", Symbiosis: A Journal of Anglo-American Relations, 11 (2), (2007), p.27-47.

Slavoj Zizek, Welcome to the Desert of the Real: Five Essays on September 11 and Related Dates, New York, Verso, 2002.

Sonia Baello-Allué, "9/11 and the Psychic Trauma Novel: Don DeLillo's Falling Man" Atlantis, Journal of the Spanish Association of Anglo-American Studies. Vol. 34-1, pages 63-79, June, 2012.

Stacey Olster (ed.), Don DeLillo Mao II, Underworld, Falling Man, Continuum Studies in Contemporary North American Fiction, London, Contunnum, 2011. Tom Junod, “The Falling Man”, Esquire online (September 8, 2009), (http://www.esquire.com/features/ESQ0903-SEP_FALLINGMAN, consulted in 2014.01.06). 